\title{
Organic matter reactivity indicators in sediments of the St. Lawrence Estuary
}

Mohammad Alkhatib ${ }^{1,2}$, Carsten J. Schubert ${ }^{3}$, Paul del Giorgio ${ }^{2}$, Yves Gelinas ${ }^{1,4}$, Moritz F. Lehmann $^{5 *}$

${ }^{1}$ GEOTOP-UQAM-McGill, CP 8888, succ. Centre-Ville, Montréal, Québec, Canada, H3C 3P8

${ }^{2}$ Département des Sciences Biologiques, Université du Québec a Montréal (UQAM), CP 8888, Succ.

A. H3C 3P8, Montréal, Québec

${ }^{3}$ Eawag, Swiss Federal Institute of Aquatic Science and Technology, Department of Surface Waters

- Research and Management, Seestrasse 79, 6047 Kastanienbaum, Switzerland

${ }^{4}$ Department of Chemistry and Biochemistry, Concordia University, 7141 Sherbrooke St. West, Montreal, Quebec, Canada H4B 1R6

${ }^{5}$ Department for Environmental Science, Bernoullistrasse 30, Universität Basel

CH-4056 Basel, Switzerland

*To whom correspondence should be addressed: moritz.lehmann@unibas.ch; phone: +41-612673616; fax: +41-61-2670479

Keywords: St. Lawrence Estuary, organic matter reactivity, amino acids, chlorins, reactivity index, organic matter degradation 


\section{Abstract}

Here we report multiple parameters used to describe the diagenetic state of sediments, including total hydrolysable amino acid (THAA), amino acid enantiomer, chlorin (CI) and amino acid degradation (DI, RI) indices, along a transect between the Upper St. Lawrence Estuary and the Gulf of St. Lawrence, Canada. The study area is characterized by gradients in water oxygen concentration, water depth, organic matter (OM) source, primary productivity, and sedimentation rate. Both CI and DI indicate a decline in OM reactivity with the transition from a more terrestrial to a more marinedominated sedimentation regime as one moves from the shallow Upper Estuary (23-95m) to the hypoxic, mid-depth Lower Estuary and to the deep ( $>400 \mathrm{~m})$, well-oxygenated Gulf. Whereas the CI more accurately reflected $\mathrm{OM}$ reactivity in surface sediments and sediments down to $5 \mathrm{~cm}$, the amino acid-based degradation indices (DI and RI) better described degradation in sediments down to $35 \mathrm{~cm}$. Systematic variations in the amino acid composition along the Laurentian Channel confirmed the increased diagenesis of OM with distance from the Upper St. Lawrence Estuary. The ratio of D/L stereoisomers of alanine increased along the transect, and the co-variation between DI and the D/LAla suggest a close coupling between the extent of diagenesis and the accumulation and selective preservation of bacterially-derived cell wall material in the sediments. The same patterns that we observed along the estuarine transect were present down-core in two sediment cores, confirming the robustness of our reactivity indices. Oxygen exposure time of the sediments appears to strongly determine sediment OM reactivity in the St. Lawrence Estuary. The sediment oxygen regime itself is related to the interplay between water column depth, vertical OM flux, and reactivity of settling OM. 


\section{Introduction}

The susceptibility of individual components of particulate organic matter (OM) to degradation during transport and burial in estuarine sediments under variable depositional conditions has long been discussed (e.g., Burdige, 2007; Niggemann et al., 2007). Key factors that influence particulate OM degradation and preservation include water column depth, redox conditions, particulate OM fluxes, sedimentation rate, sediment physical properties and microbial activity. The latter depends mainly on the nutritional quality and availability for microbes, generally defined as the OM bioreactivity (Gray et al., 2002). There is no single explanation for what exactly controls the turnover of bulk OM in general, and single components in particular, in estuaries (Hopkinson and Smith, 2005). The coincidence of spatial variations of several environmental factors can make it very difficult to separate the influence of individual factors at any given location.

The origin of the OM supplied to the sediments is one of the main factors that determines the composition and reactivity of sedimentary OM (Burdige, 2007). Whereas the production and degradation of autochthonous OM occurs entirely within the marine environment, terrestrial OM is produced and transported on land and may already be significantly altered before entering the marine system (Hedges et al., 1995). Shifts in the relative importance (marine vs. terrestrial) of the particulate OM flux at the sediment surface may influence OM reactivity and degradation in sediments. The general perception is that terrestrially-derived OM is rather recalcitrant. As a consequence, sediments dominated by terrestrial inputs can be expected to be less reactive than sediments that contain mostly autochthonous algal OM, at least if early diagenetic processes are of secondary importance.

Another factor that influences sedimentary OM diagenesis is the local redox condition. The efficiency of different respiration pathways (e.g., oxic vs. anoxic) with regards to the rates and degree of OM degradation has been investigated in laboratory experiments and the field (e.g., 
Lehmann et al., 2002; Pantoja et al., 2009). Furthermore, bulk organic carbon (C) preservation has been shown to be directly related to the oxygen exposure time of sinking and settling particles (Hartnett et al., 1998; Hedges et al., 1999), and redox oscillations have been found to enhance OM degradation largely by promoting symbiosis of aerobic and anaerobic microorganisms (Aller, 1994).

A major challenge in our understanding of OM dynamics in estuarine sediments is the actual description and quantification of the diagenetic state or reactivity of the sedimentary OM pool. Generally, bulk descriptors of sediments such as organic carbon content or carbon-to-nitrogen atomic ratio, explain little of the variation in benthic heterotrophic OM degradation rates at neither local nor regional scale (Zimmerman and Canuel, 2001; Hopkinson and Smith, 2005). Therefore, a number of bioindicators have been proposed to determine the relative degradation state of OM (e.g., Cowie and Hedges, 1994; Dauwe et al., 1999; Schubert et al., 2005). In particular, protein amino acids (AA) and chlorins (i.e., chlorophyll and its early degradation products), have been used as indicators for the overall state of OM degradation (Dauwe et al., 1999; Schubert et al., 2005). Also, the relative abundance (mole \%) of the non-protein amino acids $\beta$-Alanine (BALA) and $\gamma$-Aminobutyric acid (GABA) increase as OM is degraded, thus providing additional information on the degradation state of total OM (Cowie and Hedges, 1994; Keil et al., 2000).

Other diagenetic indicators are directly related to microbial processes in the sediments. Bacterial cell death produces bacterial remnants consisting of a variety of components that have variable susceptibilities towards degradation (Lomstein et al., 2009). One of the more refractory components is peptidoglycan, a unique constituent of bacterial cell walls containing D-amino acids (Grutters et al., 2002). D-AAs in aquatic systems, usually reported relative to their respective ubiquitous Lstereoisomers as D/L-AA ratios can thus be used as indicator of bacterial biomass (Grutters et al., 2002; Veuger et al., 2005). Indeed, the D-alanine to L-alanine (D/L-Ala) ratio of sediments generally 
increases during early diagenesis as bacterially produced OM accumulates (Lomstein et al., 2006, 2009).

These various indices of sedimentary OM target related but distinct facets of sediment OM quality and diagenetic state, and most likely provide complementary information. Yet the links that exist between them, and with other environmental factors, are still not well understood. The Laurentian Channel of the Saint Lawrence Estuary (Fig. 1) displays pronounced spatial variations in OM source, water column depth, surface water productivity, and water column DO concentration, and hence provides an excellent test case to study the environmental controls on sediment OM reactivity. In this study we combined the indicators described above, with bulk chemical and isotopic measures of sediment OM, to explore patterns in diagenetic state OM along the St. Lawrence Estuary and their links to OM sources and depositional regime.

\section{Sampling and Methods}

\subsection{Study site and sampling}

The Lower St. Lawrence Estuary and the Gulf form a semi-enclosed sea connected to the Atlantic by the south-eastern Cabot Strait (Fig. 1). The estuary is divided into the Lower Estuary and the Upper Estuary near the mouth of the Saguenay Fjord, where average water depth drops suddenly from $\sim 100 \mathrm{~m}$ to $\sim 300 \mathrm{~m}$. The morphology of the Lower Estuary and the Gulf is dominated by the Laurentian Channel, a $1200 \mathrm{~km}$ long submarine canyon that stretches from the mouth of the Saguenay Fjord through the Gulf of St. Lawrence and the Cabot Strait to the edge of the continental shelf.

The Upper Estuary is characterised by extremely low net sedimentation, with less than $10 \%$ of its total surface area covered with fine sediment deposits (d'Anglejan, 1990). On average, the suspended particulate matter load discharged by the St. Lawrence River to the Lower Estuary and the Gulf of 


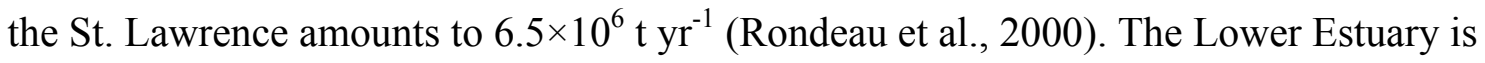
characterized by elevated sedimentation rates and a comparatively high primary productivity due to the upwelling of nutrient-rich deep water masses. Both surface water primary productivity and sedimentation rates decrease eastward along the Laurentian Channel (the latter from $0.45 \mathrm{~g} \mathrm{~cm}^{-2} \mathrm{yr}^{-1}$ at the head of the Laurentian Channel to $0.04 \mathrm{~g} \mathrm{~cm}^{-2} \mathrm{yr}^{-1}$ in the Gulf; Roy et al., 2008; see Table 1).

Recent studies of the Laurentian Channel revealed that approximately $1300 \mathrm{~km}^{2}$ of the seafloor are perennially overlain by severely hypoxic waters $(<20 \%$ saturation $)$ since the mid- 1980 s, in part due to high OM input (Gilbert et al., 2005; Lehmann et al., 2009). The oxygen-deficient area is confined within the bottom waters of the Lower Estuary in the Laurentian Channel (Table 1), and is isolated from the oxic upper layers by a steep density gradient that only allows weak diffusion of oxygen through its boundary (Gilbert et al., 2005).

Surface sediments were collected with a Van Veen grab in the Upper Estuary (Sta. DE, G, and H), and a multicorer was used in the Lower Estuary (Sta. 25-21) and Gulf (Sta. 20-16, and Anticosti) during two summer 2006 cruises (June and August) aboard the $R / V$ Coriolis II (Fig. 1; Table 1). Sediment cores were sub-sampled by slicing at $1-\mathrm{cm}$ intervals within the upper $10 \mathrm{~cm}, 2-\mathrm{cm}$ intervals between 10 and $20 \mathrm{~cm}$, and $3-\mathrm{cm}$ intervals below $20 \mathrm{~cm}$. Sediment samples were kept frozen in sterilized plastic bags prior to lyophilisation, homogenization, and analysis in the laboratory. In the following sections we distinguish between down-core records from multicores, and surface sediments. For surface sediments in the Lower Estuary and the Gulf, measured parameters represent the average of the uppermost $4 \mathrm{~cm}$ of the sediment column.

\subsection{Elemental and isotope analysis}

$\mathrm{C}_{\text {org }}$ and nitrogen $(\mathrm{N})$ contents of sediments were determined using an elemental analyzer ( $\mathrm{NC}$ Instruments). Prior to organic carbon analyses, inorganic carbon was removed by acidification of 
sediment sub-samples with concentrated $\mathrm{HCl}$ fumes overnight (Hedges and Stern, 1984). The C/N ratio was calculated as the molar ratio of $\mathrm{C}_{\text {org }}$ to $\mathrm{N}$. Reproducibility based on standard deviation of replicate measurements was better than $0.01 \%$ for $\mathrm{N}$ and better than $0.04 \%$ for $\mathrm{C}_{\text {org }}(\mathrm{n}=10)$.

The $\mathrm{C}$ and $\mathrm{N}$ isotope composition was determined using a continuous flow isotope-ratio mass spectrometer (Micromass Isoprime) coupled to a Carlo-Erba elemental analyser. $\mathrm{C}$ and $\mathrm{N}$ isotope ratios are reported as $\delta^{13} \mathrm{C}_{\text {org }}$ and $\delta^{15} \mathrm{~N}$, respectively, where $\delta$-values are denoted as \%o-deviation from the carbon isotopic composition of the Pee Dee Belemnite (PDB) standard, and from the isotope composition of atmospheric nitrogen gas (AIR), respectively: $\delta^{13} \mathrm{C}_{\text {org }}\left(\right.$ or $\left.\delta^{15} \mathrm{~N}\right)=\left[\left(\mathrm{R}_{\text {sample }} / \mathrm{R}_{\text {standard }}\right)-1\right]$ $\mathrm{x} 1000$, where $\mathrm{R}$ is either the ${ }^{13} \mathrm{C} /{ }^{12} \mathrm{C}$ ratio or the ${ }^{15} \mathrm{~N} /{ }^{14} \mathrm{~N}$ ratio. Average standard deviations based on replicate measurements were better than $0.2 \%$ for both $\delta^{15} \mathrm{~N}$ and $\delta^{13} \mathrm{C}_{\mathrm{org}}$.

\subsection{Chlorins and Chlorin Index (CI)}

Chlorins were extracted by successive (3) sonication of freeze-dried ground sediments (10-20 mg) in acetone (HPLC grade) following the procedure described by Schubert et al. (2005). Extracts were kept in dark and on ice to prevent any degradation prior to analysis, and were measured fluorometrically (Cary Eclipse 50 fluorescence spectrophotometer) at an excitation wave length of $407 \mathrm{~nm}$ and an emission wavelength of $662 \mathrm{~nm}$ (Schubert et al., 2005). Pheophytin-a from the acidification ( $\mathrm{HCl} 25 \%$ ) of a Chlorophyll-a (Sigma) standard was used for calibration. Chlorin concentrations are reported as $\mu$ g per gram dry weight sediment ( $\mu$ g gdws-1). The precision of the method was better than $7 \%(n=5)$. The chlorin index $(\mathrm{CI})$ is the ratio of the fluorescence of the acidified to the original extract. The CI scale ranges from 0.2 for pure chlorophyll to almost 1 for highly degraded pigments (Schubert et al., 2005).

\subsection{Hydrolysable amino acid analysis}


Total hydrolysable AA (THAA) were extracted by adding $5 \mathrm{~mL} \mathrm{HCl}(6 \mathrm{M})$ to freeze dried homogenized sediment $(\sim 100 \mathrm{mg})$ in pre-cleaned and muffled $\left(450 \mathrm{C}^{\circ}\right.$ for $\left.3 \mathrm{~h}\right)$ glass vials, and purging the headspace with $\mathrm{N}_{2}$. The vials were kept in an oven at $110 \mathrm{C}^{\circ}$ for $24 \mathrm{~h}$. Acid hydrolysates were then centrifuged (5000 rpm; $10 \mathrm{~min}$.$) and neutralized with 6N KOH. Individual AAs glycine (Gly),$ aspartic acid (Asp), glutamic acid (Glu), serine (Ser), threonine (Thr), arginine (Arg), alanine (Ala), $\beta$-alanine (BALA), $\gamma$-aminobutyric acid (GABA), tyrosine (Tyr), valine (Val), methionine (Met), phenylalanine (Phe), isoleucine (ILeu), and leucine (Leu) were quantified according to Lindroth and Mopper (1979) by high-performance liquid chromatography (HPLC, JASCO System) after precolumn derivatisation with OPA using a Nova-Pack C-18 column (at $25^{\circ} \mathrm{C}$ ). Blanks showed negligible AA concentrations. THAA concentration was calculated as the sum of the individual amino acid concentrations. Concentrations of the stereoisomers D- and L-Ala were measured following the method of Mopper and Furton (1999). Isobutyryl-L-cysteine was used as an additional chiral agent (Brückner et al., 1995). D- and L-Ala concentrations were corrected for racemization during acid hydrolysis according to Kaiser and Benner (2005). The percentage of racemization used for D-Ala was $1.2 \%$.

\subsection{Amino acid-based reactivity (Degradation Index)}

The Degradation Index (DI) was calculated for whole depth profiles at Sta.18 and 23 only, as well as for surface sediments from all stations. DI scores for the St. Lawrence samples were calculated using the mole percentages of AAs in the following formula: DI $=\Sigma_{i}\left[\operatorname{var}_{i}-A_{V G} / S_{i} D_{i}\right] * F_{i}$, where $\operatorname{var}_{\mathrm{i}}$ is the mole percentage of the AA $i$ (non-standardized), $\mathrm{AVG}_{\mathrm{i}}$ and $\mathrm{STD}_{\mathrm{i}}$ are the average and standard deviation of the $\operatorname{var}_{\mathrm{i}}$ respectively, and $\mathrm{FC}_{\mathrm{i}}$ is the factor coefficient assigned for $\operatorname{var}_{\mathrm{i}}$ on the first axis of the PCA analysis, also called variable loading (Dauwe et al., 1999). Dauwe and Middelburg (1999) determined the DI scores for different OM, and found that DI for sources such as 
phytoplankton, bacteria, and sediment trap material have DIs between 1 and 1.5, while coastal and ocean margin sediments have scores between -0.3 and 1 . Deep-sea sediments display scores less than -1 .

2.6 Oxygen penetration depth and oxygen exposure time

Adopting the approach of Cai and Sayles (1996), $\mathrm{O}_{2}$ penetration depths (OPD) were approximated based on benthic $\mathrm{O}_{2}$ flux data from Thibodeau et al. (2010; Table 1), with $\mathrm{OPD}=\left[D_{\mathrm{O} 2}^{\mathrm{s}} \mathrm{x} \mathrm{O}_{2} \_\mathrm{BW}\right] /$ $\mathrm{F}_{\mathrm{O} 2}$, where $\mathrm{F}_{\mathrm{O} 2}$ is the benthic $\mathrm{O}_{2}$ flux, $\mathrm{O}_{2} \_\mathrm{BW}$ is the bottom water $\mathrm{O}_{2}$ concentration, and $\left(D_{\mathrm{O} 2}^{\mathrm{s}}\right)$ is the sedimentary diffusion coefficient at the in situ temperature corrected for sediment porosity. Sediment $\mathrm{O}_{2}$ exposure time (OET) is calculated as the OPD divided by the corresponding sediment accumulation rate (data from Smith and Schafer, 1999; Table 1).

\section{Results}

3.1 Elemental carbon and nitrogen concentrations and isotopic composition

In surface sediments, $\% \mathrm{C}_{\text {org }}$ and $\% \mathrm{~N}$ in the Upper Estuary ranged from 2.6 to $1.5 \%$ and from 0.21 to $0.14 \%$, respectively (Fig. $2 \mathrm{a}$ ). In the Lower Estuary and the Gulf, $\% \mathrm{C}_{\text {org }}$ showed a decreasing trend, while nitrogen concentrations increased. $\mathrm{C} / \mathrm{N}$ ratios declined from $>18$ in the Upper Estuary to $<9$ in the Gulf (Fig. 2b). The $\delta^{13} \mathrm{C}_{\text {org }}$ of sediments of the Upper Estuary displayed a narrow range

between -25.8 and $-25.2 \%$, while in the Laurentian Channel, $\delta^{13} \mathrm{C}_{\text {org }}$ values increased from $-24.2 \%$ at the head of the Channel to $-22.5 \%$ at Anticosti and $-22.0 \%$ at Sta. 16 (Fig. $2 \mathrm{c}$ ). The observed $\delta^{13} \mathrm{C}_{\text {org }}$ and $\mathrm{C} / \mathrm{N}$ ratios found in the surface and core sediments along the upper estuary and the Laurentian Channel indicate different OM sources (see Smith and Epstein, 1971; Fry and Sherr, 1984). Terrigenous contribution to the OM was highest in the Upper Estuary sediments and decreased as a function of distance from the St. Lawrence River mouth. This trend is confirmed by decreasing 
lignin concentrations from the Upper Estuary towards to the Atlantic Shelf (Louchouarn et al., 1997). The $\delta^{13} \mathrm{C}_{\text {org }}$ in the Gulf sediments shows that sedimentary $\mathrm{OM}$ is mainly of marine origin, with minimal contribution of terrestrial $\mathrm{OM}$ at Sta. $16\left(\delta^{13} \mathrm{C}=-22\right.$, Fig. 2$)$. An enrichment in ${ }^{15} \mathrm{~N}$ was also observed along the terrestrial-marine gradient, with $\delta^{15} \mathrm{~N}$ values $<5 \%$ in the Upper Estuary and $>7 \%$ o at Sta. 16 (Fig. 2c). This pattern is related to incomplete nutrient utilization as described by Thibodeau et al. (2010).

Down-core, $\% \mathrm{C}_{\text {org }}$ and $\% \mathrm{~N}$ decrease at most sites (Fig. 3a,b). $\mathrm{C} / \mathrm{N}$ ratios in sediments increased with depth by $1-2$ at Sta. 25 and 23 in the Lower Estuary and by $0.5-1.5$ at the Anticosti station and Sta. 16 in the Gulf (Fig. 3c). In contrast, the $\mathrm{C} / \mathrm{N}$ ratios did not change significantly with depth in the sediments between Sta. 22 in the Lower Estuary and Sta. 19 in the Gulf (Fig. 3c). Our data indicate down-core enrichment in the ${ }^{13} \mathrm{C}_{\mathrm{org}}$ in the upper $10 \mathrm{~cm}$ of the sediment cores at Sta. $25,23,22,18$, and 16, while at the other stations the $\delta^{13} \mathrm{C}_{\text {org }}$ did not show a clear down-core trend (Fig. 3d).. We also observed a decrease in $\delta^{15} \mathrm{~N}$ by $\sim 0.5$ to $1 \%$ down-core in the uppermost $6 \mathrm{~cm}$ at Sta. $25,23,16$ and Anticosti, whereas at the other stations no clear trend could be discerned (Fig. 3e).

\subsection{Chlorin concentrations and index}

Surface sediment chlorin concentrations decreased seaward along the investigated transect (Fig. 2b). In the Upper Estuary at Sta. DE, chlorin concentrations were $>15 \mu \mathrm{g} \mathrm{g}^{-1}$ (Fig. 2b). Along the Laurentian Channel, they ranged between $12 \mu \mathrm{gg}^{-1}$ in the Lower Estuary and 4-6 $\mu \mathrm{g} \mathrm{g}^{-1}$ at Sta. 16 and the Anticosti station in the Gulf. At all stations but Sta. Anticosti, chlorin concentrations decreased with sediment depth, with $25-49 \%$ of the chlorins being lost in the upper $5 \mathrm{~cm}$ (Table 1 ). CI in surface sediments increased along the Laurentian Channel, with the lowest values (0.43-0.48) in the Upper Estuary (Sta. DE, Sta. G, and Sta. H), and the highest values (>0.81) at Sta. 16 (Fig. 4a). 
At most stations, the $\mathrm{CI}$ increased down-core in the upper sediment layer $(\sim 10 \mathrm{~cm})$, whereas, no change in CI could be discerned deeper in the sediments (Fig. 3f).

\subsection{Total hydrolysable amino acids}

THAA concentrations in the surface sediments showed a slight decrease downstream the Laurentian Channel, with highest values in the Upper Estuary $\left(50.2-58 \mu \mathrm{mol} \mathrm{g}^{-1} \mathrm{dws}\right)$, intermediate concentrations in the Lower Estuary (41-51 $\left.\mu \mathrm{mol} \mathrm{g}^{-1}\right)$, and the lowest concentrations at Sta.16 in the Gulf $\left(31 \mu \mathrm{mol} \mathrm{g}^{-1}\right.$; Fig. $\left.2 b\right)$. In the surface sediments, the percentage of $\mathrm{C}_{\text {org }}$ found in amino acids (\%THAA- $\mathrm{C}_{\text {org }}$ ) varied between 11 and 20\% in the Upper Estuary, between 12 and 19\% in the Lower Estuary, and ranged from 10 to $16 \%$ in the Gulf (Fig. 2d). Percent amino acid N (\%THAA-N) varied between 42 and 69\% in the Upper Estuary, between 42 and 60\% in the Lower Estuary, and between 23 and $42 \%$ in the Gulf (Fig. 2d). Sediment profiles at Sta. 23 and 18 showed a decrease in the THAA concentration with depth, from 41 to $23 \mathrm{mg} \mathrm{g}^{-1}$ and 37 to $23 \mu \mathrm{mol} \mathrm{g}^{-1}$, respectively (Fig. 5a). At Sta. 23 in the Lower Estuary, \%THAA-N and \%THAA- $\mathrm{C}_{\text {org }}$ decreased from 0 to $35 \mathrm{~cm}$ by $17 \%$ and 26\%, respectively, whereas at Sta. 18 in the Gulf the \%THAA-N and \%THAA-C $\mathrm{C}_{\text {org }}$ decrease was significantly more pronounced ( $31 \%$ and $29 \%$, respectively) (Fig. 5 b, c). At least for the Gulf stations, a stable input of OM to the sediments can be assumed (Genovesi et al., 2011) (we observe almost invariant profiles of carbon and nitrogen concentrations), and the \%THAA-N and \%THAA$\mathrm{C}_{\text {org }}$ trends can be interpreted as the result of fractional degradation.

\subsection{Amino acid composition and degradation index}

Surface sediment mole percentages (mole\%) of Asp, BALA, GABA, Gly, and, to a lesser extent, Arg and Thr, increased with distance seaward from the Upper Estuary, while those of Ala, Glu, ILeu, Lys, Leu, Phe, Tyr, and Val decreased along the same gradient. Met did not show a clear along- 
channel concentration gradient (Table 2). The relative AA abundance was similar in the Lower Estuary and Gulf sediments (Sta. 23 and 18; Fig. 6). Ala, Asp, Glu, Gly, Ser, and Thr were the most important AAs, comprising more than $60 \%$ of the THAA. At the two stations where we obtained AA concentration profiles (Sta. 23 and Sta. 18), Asp, Glu, Ileu, Phe, Ser, Thr, and Val decreased with depth, while BALA, GABA, Gly, and Lys increased. With regards to Ala, Arg, Leu, Met, and Tyr, only minor down-core changes were observed.

D/L-Ala increased along the Upper Estuary and the Laurentian Channel, with average values of 0.17 in the Upper Estuary, 0.22 in the Lower Estuary, and 0.32 in the Gulf (Table. 2). At both investigated stations, D/L-Ala ratios increased down-core from $\sim 0.2$ in surface sediments to $\sim 0.4$ in the deeper sediments (Fig. 5d). The DI in surface sediments ranged between -0.08 and 0.13 in the Upper Estuary, -0.4 and -0.53 in the Lower Estuary, and -0.5 and -1.0 in the Gulf (Fig. $4 b$ ). DI decreased down-core at both Sta. 18 and Sta. 23, (Fig. 5e) from $\sim-0.6$ to -0.8 and from -0.4 to -0.5 , respectively.

\section{Discussion}

\subsection{Relative loss of chlorins and THAA}

Our THAA concentrations in surface sediments along the estuary (upper and lower) and the Gulf (Fig. 2b) are typical for natural estuarine and coastal marine environments (Cowie and Hedges, 1992; Lomstein et al., 2006; Arnarson and Keil, 2007). Chlorin concentrations were one order of magnitude higher than those found in the Arabian Sea sediments (Schubert et al., 1998; Shankle et al., 2002), but one order of magnitude lower than values reported from Lake Zug sediments (Meckler et al., 2004). The absolute percentage of THAA and chlorins is influenced by the overall OM fluxes and, hence, is a function of primary productivity (which varies along the estuary and between the estuary and the Gulf). Chlorin and THAA concentrations normalized to $\mathrm{N}$ and $\mathrm{C}_{\text {org }}$ concentrations, 
on the other hand, reflect changes in degradation state (Lee et al., 2000; Lomstein et al., 2006; Schubert et al., 2005) or changes in the terrestrial-to-marine OM ratio. Normalized THAA concentrations decrease downstream (Fig. 2d) and down-core (Fig. 5b,c), consistent with the preferential degradation of AAs relative to bulk $\mathrm{N}$ and $\mathrm{C}_{\text {org }}$ with ongoing OM degradation (Burdige and Martens, 1988; Cowie and Hedges, 1992). The degree of chlorin and THAA degradation most likely reflects the intensity of early diagenesis (either in the water column or within the sediments), and the lower chlorin concentrations in the Gulf hints to a more advanced degradation. Along the same line, the comparatively high chlorin and THAA concentrations in the Upper Estuary can be explained by a better OM preservation in shallower waters. Indeed, a significant exponential relationship exists between vertical OM flux in the water column (obtained from previously published studies in the same area, see Table 1) with surface sediment chlorin concentration per 100 mg $\mathrm{C}_{\text {org }}$ (Table $\left.1 ; \mathrm{r}^{2}=0.41, \mathrm{n}=6\right)$, as well as with surface sediment \%THAA-N $\left(\mathrm{r}^{2}=0.68, \mathrm{n}=6\right)$. The more seaward stations in the eastern Lower Estuary and the Gulf are typically nutrient-depleted leading to low productivity (Roy et al., 2008; Thibodeau et al., 2010), whereas the western landward Lower Estuary is generally more productive (Gilbert et al., 2005), and therefore sustains higher OM fluxes.

Pelagic processes (e.g., OM flux, OM decomposition and transformation) affect the biogeochemical composition and reactivity of the sinking OM that reaches the sediments; it is thus $a$ priori difficult to determine whether the observed along-channel changes in the composition of the surface sediments are due to reworking in the water column or the result of post-depositional processing. In this regard, the patterns of chlorin and total OM loss down-core in the sediments can be used as an index of the intensity of post-burial diagenesis. Along the Laurentian Channel, between $16 \%$ and $50 \%$ of the surface sediment chlorin was lost in the upper $5 \mathrm{~cm}$ of the sediment column (Fig. 3g, Table 1). The highest chlorin loss (see Table 1 for definition) was observed at the head of 
the Laurentian Channel, in the hypoxic portion of the Lower Estuary, while minimal loss was observed at Sta. 16 in the Gulf (Table 1). Enhanced down-core chlorin loss at the shallower, low-DO stations (Sta. 25 to 21) suggests that, here, chlorins are less effectively degraded in the water column and quantitative degradation sets in upon deposition at the sediment surface. At the deeper stations in (e.g., Sta. 16) particle oxygen exposure time is increased and chlorins are significantly degraded already during settling through the water column, leaving less chlorin "substrate" for degradation in the sediments.

Sedimentation rates at the Lower-Estuary stations are higher than at the Gulf sites (Table 1). As a consequence, the integrative $(4 \mathrm{~cm})$ surface sediment samples have a different ages and some of the along-channel biogeochemical variations are likely attributable to those differences. However, the variability of chlorin and THAA loss in down-core sequences (representing longer timescales compared to the surface-sediment age difference between stations) is much less than in surface sediments along the Upper Estuary to Gulf transition; these age differences alone thus cannot explain the observed along-channel trends.

\subsection{Amino acid composition changes and reactivity indices}

AAs display variable susceptibility towards bacterial decomposition and reworking. Due to their comparatively labile nature and high nutritional value for bacteria, Glu, ILeu, Leu, Tyr, and Phe are preferentially degraded in sediments during early diagenesis (Burdige and Martens, 1988; Dauwe et al., 1999; Lee et al., 2000). Lee et al. (2000) observed that Glu, Phe, and Tyr decrease as particles sink in the water column at various locations in the Central Equatorial Pacific Ocean. In surface sediments along the Laurentian Channel, a general trend of higher concentrations of these AAs upstream and lower concentrations downstream (Table 2) can, therefore, be interpreted as an increase in OM degradation state towards the open waters. 
In surface sediments along the terrestrial-marine gradient, Lys decreased while Asp increased (Table 2). Cowie and Hedges (1992) have shown that Lys is enriched in vascular plant OM compared to marine phytoplankton. Therefore, the observed relative Lys concentration decrease, together with the observed $\mathrm{C} / \mathrm{N}$ and $\delta^{13} \mathrm{C}_{\text {org }}$ changes, confirm the decreasing trend in the amount of terrestrial plant material deposited in downstream sediments. Nunn and Keil (2005) found that enrichment in Asp during OM degradation is likely due to both preferential preservation of Asp-rich proteins and the production of Asp during bacterial reworking (Nunn and Keil 2005). Both processes likely contributed to the observed relative enrichment of Asp downstream.

The increase in \% Gly both downstream along the Upper Estuary and the Laurentian Channel (Table 1) and down-core at Sta. 18 and 23 (Fig. 6a) suggests that Gly preferentially accumulates during OM degradation. Dauwe and Middelburg (1998) interpreted the enrichment in Gly as a consequence of its low nutritional value for benthic fauna and microbial communities, whereas Lee et al. (2000) suggested enrichment in Gly due to selective diatom cell wall preservation. Gly is also an important component found in bacterial cell walls (Lee et al., 2000; Ingalls et al., 2003). In contrast to bacterial cell walls, diatom cell walls and frustules are also enriched in Ser and Thr, in addition to Gly (Ingalls et al., 2003). Ser decreased both downstream in surface sediments and downcore at both investigated stations. Thr on the other hand decreased down-core at Sta. 18 and did neither change down-core at Sta. 23 nor downstream in surface sediments. Hence, the most plausible assumption is that it is indeed the increasing contribution of bacterial necromass to the bulk sediment OM pool with ongoing degradation (Keil et al., 2000), in addition to diagenetic alteration of other AAs that leads to the relative enrichment of Gly within the St. Lawrence Estuary and Gulf sediments. Progressive diagenesis in sediments is also indicated by the increased abundance of non-protein AAs (Cowie and Hedges, 1994; Hedges et al., 1999; Lee et al., 2000). We found a pronounced increase in the relative abundance of BALA and GABA, both in surface sediments along the studied 
transect towards the Gulf (Table 2), and down-core (Fig. 6p,q), which can be interpreted as an additional indicator of compositional changes of the sedimentary OM due to the more advanced state of degradation, respectively. The patterns of individual AAs are coherent with the values determined for the DI, both converging to suggest declining reactivity (i.e., more advanced degradation) in surface sediments along the Upper Estuary and the Laurentian Channel (Fig. 4b), and with depth in sediments at Sta. 18 and 23 (Fig. 5e).

Consistent with the DI scores, surface sediment CI values in the Upper Estuary were lower compared to those in the Lower Estuary and the Gulf, also indicating a lower degree of alteration (Fig. 4a). Overall, the DI and CI suggest that the most degraded and least reactive sediments occur in the Gulf. The agreement between DI and CI in surface sediments along the Laurentian Channel is better $\left(r^{2}=0.89, n=12\right.$; Fig. $\left.7 a\right)$ than for the down-core records $\left(r^{2}=0.43, n=39\right)$. Because chlorins and amino acids are molecularly different compounds, they are likely to be degraded at different rates (Meckler et al., 2004). As becomes evident from our data set, the CI is only very sensitive in surface sediments and down to the first five centimeters in the two investigated cores. Below $5 \mathrm{~cm}$ sediment depth, hardly any change in the CI can be discerned. This is in agreement with a previous study by Meckler et al. (2004), showing that the CI is more sensitive at early stages (i.e., years) of OM degradation.

Our interpretation of the trends in the DI and CI is further supported by a third reactivity indicator (Reactivity Index, or RI), which is based on the ratio of aromatic AA (Phe+Tyr) to non-protein AA (GABA+BALA), and which varies from 0.1 for heavily degraded OM to 3.6 for freshly deposited reactive OM (Jennerjahn and Ittekkot, 1997). As with the other indices, the RI suggests that surface sediments in the more seaward parts of the St. Lawrence Estuary and the Gulf are more degraded than in the Upper Estuary and the estuarine channel mouth (Fig. 4c). The good agreement between 
$\mathrm{CI}$ and the other AA-based reactivity indices (Fig. 7) supports the robustness of those indices in transitional aquatic environments such as the St. Lawrence Estuary.

\subsection{Bacterial OM}

Unlike L-AAs, the D-AAs are source-specific and therefore have the potential to indicate OM origin (McCarthy et al., 1998; Amon et al., 2001). D-Ala is present in all bacteria providing a robust tracer for bacterial biomass (e.g., Amon et al., 2001; Grutters et al., 2002; Veuger et al., 2005; Jørgensen and Middelboe, 2006). An increasing proportion of D-Ala with depth and age of the sediment can, in addition to bacterial synthesis, be the result of chemical racemization. However, this possibility was tested in various coastal and continental shelf studies (Pedersen et al., 2001; Grutters et al., 2002; Lomstein et al., 2006), confirming that biological processes generally dominate the production of D-AA. The increase in D/L-Ala in surface sediments downstream (from an average of 0.17 in the Upper Estuary to 0.22 in the Lower Estuary, and to 0.32 in the Gulf; Table 2) suggests the enrichment of the OM pool with bacterial remnants. Moreover, D/L-Ala increases down-core at Sta. 23 and 18 (Fig. 5d), demonstrating the accumulation of bacterial remnants during sedimentary diagenesis. Similar observations have been made in other marine environments, such as the Aarhus Bay and Roskilde Fjord, Denmark (Pedersen et al., 2001; Jørgensen and Middelboe, 2006), the northeastern Atlantic continental slope (Grutters et al., 2002), and in coastal sediments off Chile and Peru (Lomstein et al., 2006, 2009). D/L-Ala ratios can further be used to estimate the relative contribution of bacterial remnants to bulk sedimentary OM preserved in the sediments. The strong inverse correlation between D/L-Ala and the reactivity indicator DI, both downstream $\left(\mathrm{r}^{2}=0.83\right.$, $\mathrm{n}=12$ ) and down-core at Sta. 23 and 18, indicates a close link between the degradation state and the degree of bacterial processing of sedimentary OM. A similar correlation between DI and D-AA enrichment has been found for marine dissolved OM (Amon et al., 2001) supporting the concept that 
bacteria not only consume labile organic material but replace it with OM that is more refractory in nature. Alternatively, if not refractory per se, bacterial OM may be continuously and efficiently recycled to maintain a stable "bacterial" OM signature in the sediments. These details aside, our observations in the St. Lawrence Estuary and Gulf are consistent with previous reports, which show that bacterial remnants are preferentially preserved both in laboratory incubations and marine sediments (Tremblay and Benner,, 2006; Veuger et al., 2005; Lomstein et al., 2009), and thus confirm that bacterial degradation and biosynthesis shape the chemical composition of OM by selectively removing bio-reactive components from the original OM and leaving behind (biorefractory) bacterial OM components (e.g., peptidoglycan).

\subsection{Environmental factors}

Both the chlorin-based and AA-based reactivity indices suggest that the reactivity of the sedimentary OM declines along the Upper Estuary- Gulf gradient transition. The factors that control this reactivity gradient is, however, not clear. In order to explore this question in detail, we compared the OM reactivity in surface sediments to water depth, bottom water oxygen content, and oxygen exposure time.

\subsubsection{Water column depth}

Despite similar environmental conditions in the Upper Estuary (Sta. DE, G, and H) and at Sta. 16, OM reactivity is much greater at the shallow sites in the Upper Estuary, suggesting that water depth may be an important determinant of the quality of the sedimentary OM. In fact, we found a significant correlation between water depth and the $\mathrm{CI}\left(\mathrm{r}^{2}=0.92, \mathrm{n}=12\right.$; Fig. $\left.8 \mathrm{a}\right)$, providing putative evidence that the settling time of organic particles and aggregates in the water column plays a crucial role in determining the quality of OM that ultimately reaches the sediments. Particle-associated 
bacteria degrade organic compounds from sinking particles, leading to the production of dissolved OM (Honjo et al., 2008 and references therein), while breaking the sinking particles down into smaller, suspended OM particles, thus reducing the overall OM particles flux and inducing compositional changes. This process is drastically reduced when water depth is shallow like in the upper estuary. Co-variation of sediment OM reactivity and water column depth was observed in other environments as well (Hedges et al., 1999; Shankle et al., 2002; Lomstein et al., 2006). Niggemann et al. (2007) compared depositional conditions, OM composition, and organic carbon turnover in sediments from two different depositional systems along the Chilean continental margin, and in agreement with our observations, concluded that water depth plays an important role in the quality of sinking OM. Along the same line, Shankle et al. (2002) found a significant correlation between sediment chlorin concentration and water column depth in the Arabian Sea. Hedges et al. (1999) found that with increasing water column depth off shore the continental margin of Washington, the fraction of GABA and BALA increased in the sedimentary OM, indicating advanced degradation of the sediments. Bourgoin and Tremblay (2010) collected suspended particles at different water column depths in the St. Lawrence Estuary. Consistent with our findings of a depth-controlled reactivity of the Upper vs. Lower Estuary sediments, they found that in the Lower Estuary, bottom water particulate THAA concentrations were up to 35 times lower compared to surface water concentrations, while in the Upper Estuary THAA loss with depth in the water column was minimal.

\subsubsection{Dissolved oxygen and vertical OM flux}

In the Lower Estuary and the Gulf, water depth variations are less pronounced than between the Upper Estuary and Lower Estuary. Nevertheless, surface sediment reactivity appears to decrease eastward (Fig. 4). We found a significant negative relationship between CI in surface sediments and 
the $\mathrm{C}_{\text {org }}$ flux to the sediments (see Table 1 with references therein; $\mathrm{r}^{2}=0.87, \mathrm{n}=5$; Fig. $8 \mathrm{~b}$ ), and a positive relationship with the bottom water DO content $\left(r^{2}=0.86, n=9 ;\right.$ Fig. $\left.8 c\right)$. This suggests that low DO conditions and enhanced fluxes of OM to the sediments combine to enhance OM preservation in the Lower Estuary sediments. Increased sedimentation rates have been hypothesized to be responsible for increased OM preservation through rapid burial (Henrichs and Reeburgh, 1987; Bertrand and Lallier-Verges, 1993). Ambient oxygen concentration also partly control the extent of OM degradation in the water column and in sediments, both on short and long time scales (Bianchi et al., 2000; Kristensen and Holmer, 2001; Bechtel and Schubert, 2009). It is important to note, however, that the initial rate of fresh bulk OM remineralization occurs at similar rates under both oxic and hypoxic to anoxic conditions, while that of older and refractory OM seems to be slower under anaerobic compared to oxic conditions (Lehmann et al., 2002; Pantoja et al., 2009; Bechtel and Schubert, 2009). Chlorins appear to be more susceptible to oxic degradation (Sun et al., 1993; Shankle et al., 2002). The strong correlation between CI (and DI, $\mathrm{r}^{2}=0.93, \mathrm{n}=9$ ) and bottom water oxygen concentration suggests that OM delivered to sediments in the Lower Estuary and Gulf may be partially degraded in the water column or in the bottom nepheloid layer, to a degree that allows the oxygen to play a role on preferential preservation of OM under low oxygen concentration condition, in agreement with the findings of Archer and Devol (1992) and Bourgoin and Tremblay (2010). We also note that oxygen concentrations only correlate with specific components (here pigments and AA) and do not correlate significantly with total $\% \mathrm{C}_{\text {org }}$ in surface sediments $\left(\mathrm{r}^{2}=0.19\right.$, $\mathrm{n}=9$ ). Similar uncoupling between $\% \mathrm{C}_{\text {org }}$ and DO has been observed across the Indus margin of the Arabian Sea (Cowie et al., 2009) and across the Washington State continental shelf and slope (Archer and Devol, 1992).

The effects of DO concentrations and OM sedimentation rates combine to determine yet another factor that is likely to have close links to the reactivity of sedimentary OM: The exposure time 
(OET) of organic particles to oxic conditions within the sediments. The OET depends on the burial rate and the oxygen penetration depth (OPD) in the sediments, which in turn is a direct function of the DO in the overlying water and the reactivity of sediments (Hartnett et al., 1998; Hedges et al., 1999; Lehmann et al., 2009). The calculated OPD in the St. Lawrence estuarine sediments (corresponding to the thickness of the oxic sediment layer) increases from approximately $0.6-0.9 \mathrm{~cm}$ in sediments at the head of the Laurentian Channel at Sta. 25 and Sta. 23 to approximately $1.5-1.8$ $\mathrm{cm}$ in the Gulf at Sta. 18, 19, and Anticosti. Similar values for the OPD (1.5 to $1.7 \mathrm{~cm})$ were measured for the St. Lawrence Gulf sediments by Silverberg et al. (2000) using microelectrodes. A negative correlation between OPD and OM reactivity (DI; $\left.\mathrm{r}^{2}=0.73 ; \mathrm{n}=6\right)$ indicates that the sedimentary OM reactivity decreases as OPD increases, yet the causal links are not obvious. OET was lowest in the Lower Estuary, ranging between 1.2-1.7 years at Sta. 25 and Sta. 23, increasing to $\sim 7$ years between Sta. 21 and Sta. 19, and reaching $\sim 14$ years at Sta. 18. As with OPD, OET correlates with OM reactivity (DI; $\mathrm{r}^{2}=0.88 ; \mathrm{n}=5$; and $\mathrm{CI} \mathrm{r}^{2}=0.72 ; \mathrm{n}=5$ ). There are several components of OM that are oxygen-sensitive (Hedges et al., 1999), and have higher potential to be preserved under reducing conditions or shorter OET of years and decades (Arnarson and Keil, 2007). Both high OM flux and low bottom-water DO (Table 1) at the head of the Laurentian Channel are conducive to shorter OET and shallower OPD. While our data indicate that oxygen exposure time of the sediments determines OM reactivity, the sediment oxygen regime may itself be related to the reactivity of the sedimenting OM. Direct (through core incubations) and indirect (porewater DO profiles) determinations of benthic $\mathrm{O}_{2}$ fluxes carried out by Thibodeau et al. (2010) revealed that oxic bacterial respiration rates along the Laurentian Channel are a function of the sediment reactivity rather than OM content. Hence, we argue that feedback loops can be created wherein the reactivity of the OM may influence the establishment of hypoxic conditions, which in turn, may enhance the preservation of OM in the sediment. 


\section{Conclusions}

In this paper we have explored the relative importance of OM sources versus processing in determining the sediment OM reactivity along estuarine gradients. Terrestrially-derived OM has traditionally been considered recalcitrant, and thus sediments dominated by terrestrial inputs would be expected to be less reactive than those dominated by algal materials. Our results do not support this assumption. The various compositional characteristics of the studied sediments suggest a trend towards less reactive material from the Upper Estuary towards the Gulf, while geochemical evidence highlights the transition from a more terrestrial to a more marine- dominated sedimentation regime along this transect. The agreement between chlorin- and amino acid-based reactivity indicators (CI, DI, RI) demonstrates the applicability of both types of indices to complex estuarine environments with terrestrial and marine organic matter sources. The CI better describes the initial degradation of OM (i.e. in the water column and the uppermost sediments), whereas the amino acid-based indicators also account for longer-term degradation processes in the deeper sediment. The spatial pattern in sediment reactivity along the Laurentian Channel seem to primarily result from increasing intensity of OM degradation in the water column and within the sediments. Hence, our data provide a good example where OM source seems to be secondary to early diagenetic processing in determining sediment reactivity. We provide putative evidence that water depth (which influences particle settling time), OM flux rates and bottom water DO all play a role in OM preservation and thus control the bulk OM reactivity of the sediments. The observed trends towards higher D/L Ala ratios in surface sediments downstream the Laurentian Channel (and down-core), indicate the accumulation of bacterial remnants with increasing OM degradation, and parallels the DI and CI changes. Hence the preservation and accumulation of bacterial cell wall remnants is coherent with the patterns of reactivity, confirming 1) the close link between OM degradation, in situ bacterial biosynthesis, and 
the preservation of $\mathrm{OM}$ and 2) the refractory nature of the preserved (or continuously recycled) bacterial material. While our data suggest that bottom water DO is an important constraint on OM degradation and reactivity, we speculate that OM reactivity itself likely influences oxygen flux and penetration depth in the sediments, with direct implications for the dissolved oxygen budget and hypoxia in the Lower St. Lawrence Estuary. 


\section{Acknowledgements}

We thank the captain and crew of the RV Coriolis II. We also thank F. Vazquez and B. Seth for technical assistance, S. Pantoja for help with AA calculations, and T. Radi for help with the statistical analyses. C. Lee provided helpful comments on an earlier version of the manuscript. The review by D. Burdige and one anonymous reviewer helped to significantly improve the paper. M. Alkhatib acknowledges financial support through a GEOTOP research centre scholarship. Discovery and ship-time grants from the Natural Sciences and Engineering Research Council of Canada (NSERC) to M. F. L. and Y.G made this study possible. Laboratory funding for organic geochemical work came from internal Eawag funds to C.J.S. 


\section{References}

Aller R. C., 1994. Bioturbation and remineralization of sedimentary organic matter: effects of redox oscillation: Controls on carbon preservation. Chemical Geology 114: 331-345.

Amon, R. M. W., Fitznar, H. P., and Benner, R., 2001. Linkages among the bioreactivity, chemical composition, and diagenetic state of marine dissolved organic matter. Limnology and Oceanography 46, 287-297.

Archer, D. and Devol, A., 1992. Benthic oxygen fluxes on the Washington shelf and slope: A comparison of in situ microelectrode and chamber flux measurements. Limnology and Oceanography 37, 614-629.

Arnarson, T. S. and Keil, R. G., 2007. Changes in organic matter-mineral interactions for marine sediments with varying oxygen exposure times. Geochimica et Cosmochimica Acta 71, 35453556.

Bechtel, A. and Schubert, C.J., 2009. Biogeochemistry of particulate organic matter from lakes of different trophic levels in Switzerland. Organic Geochemistry 40, 441-454.

Bertrand, P. and Lallier-Verges, E., 1993. Past Sedimentary organic matter accumulation and degradation controlled by productivity. Nature 364, 786-788.

Bianchi, T., Johansson, S. B., and Elmgren, R., 2000. Breakdown of phytoplankton pigments in Baltic sediments: effects of anoxia and loss of deposit-feeding macro fauna. Journal of experimental marine biology and ecology 251, 161-183.

Bourgoin, L. H. and Tremblay, L., 2010. Bacterial reworking of terrigenous and marine organic matter in estuarine water columns and sediments. Geochimica et Cosmochimica Acta 74, 55935609. 
Brückner, H., Langer, M., Lüpke, M., Westhauser, T., Godel H., 1995. Liquid chromatographic determination of amino acid enantiomers by derivatization with o-phthaldialdehyde and chiral thiols Applications with reference to food science. Journal of Chromatography A 697, 229-245.

Burdige, D. J. and Martens, C. S., 1988. Biogeochemical cycling in an organic-rich coastal marine basin: The role of amino acids in sedimentary organic carbon and nitrogen cycling. Geochimica et Cosmochimica Acta 52, 1571-1584.

Burdige, D. J., 2007. Preservation of organic matter in marine sediments: controls, mechanisms, and an imbalance in sediment organic carbon budgets? Chemical Reviews 107, 467-485.

Cai, W. J., and Sayles, F. L., 1996. Oxygen penetration depths and fluxes in marine sediments. Marine Chemistry 52, 123-131.

Colombo, J. C., Silverberg N., and Gearing, J. N., 1996. Lipid biogeochemistry in the Laurentian Trough: I-fatty acids, sterols and aliphatic hydrocarbons in rapidly settling particles. Organic Geochemistry 25, 211-225.

Cowie, G. L. and Hedges, J. I., 1992. Sources and reactivates of amino acids in a coastal marine environment. Limnology and Oceanography 37, 703-742.

Cowie, G. L. and Hedges, J. I., 1994. Biochemical indicators of diagenetic alteration in natural organic mixtures. Nature 369, 304-307.

Cowie, G. L., Mowbray, S., Lewis, M., Matheson, H., and McKenzie, R., 2009. Carbon and nitrogen elemental and stable isotopic compositions of surficial sediments from the Pakistan margin of the Arabian Sea. Deep-Sea Research II 56, 271-282.

d'Anglejan, B., 1990. Recent sediments and sediment transport processes in the St. Lawrence estuary. In El-Sabh, M. I. and Silverberg, N. (Eds.), Oceanography of a Large-Scale Estuarine System: The St. Lawrence. Coastal and Estuarine Studies, Springer-Verlag, New York, Vol. 39, pp. 109-125. 
Dauwe, B., Middelburg, J. J., Herman, P., and Heip, C., 1999. Linking diagenetic alteration of amino acids and bulk organic matter reactivity. Limnology and Oceanography 44, 1809-1814.

Dauwe, B. and Middelburg, J. J., 1998. Amino acids and hexosamines as indicators of organic matter degradation state in North Sea sediments. Limnology and Oceanography 43, 782-798.

Fry, B. and Sherr, E., 1984. $\delta^{13} \mathrm{C}$ measurements as indicators of carbon flow in marine and freshwater ecosystems. Contributions in Marine Science 27, 15-47.

Gilbert, D., Sundby, B., Gobeil, C., Mucci, A., and Tremblay, G., 2005. A seventy two year record of diminishing deep water oxygen in the St Lawrence Estuary: the northwest Atlantic connection. Limnology and Oceanography 50, 1654-1666.

Gray, J., Wu, R., and Or, Y., 2002. Effects of hypoxia and organic enrichment on the coastal marine environment. Marine Ecology Progress Series 238, 249-279.

Genovesi, L., deVernal, A., Thibodeau, B., Hillaire-Marcel, C., Mucci, A., and Gilbert, D., 2011. Recent changes in bottom water oxygenation and temperature in the Gulf of St. Lawrence: Micropaleontological and geochemical evidence. Limnology and Oceanography 56, 1319-1329. Grutters, M., van Raaphorst, W., Epping, E., Helder, W., de Leeuw, J. W., Glavin, D. P, and Bada, J., 2002. Preservation of amino acids from in situ-produced bacterial cell wall peptidoglycans in northeastern Atlantic continental margin sediments. Limnology and Oceanography 47, 15211524.

Hartnett, H. E., Keil, R. G., Hedges, J. I., and Devol, A. H., 1998. Influence of oxygen exposure time on organic carbon preservation in continental margin sediments. Nature, 391: 572-574.

Hedges, J. I. and Stern, J., 1984. Carbon and nitrogen determinations of carbonate containing solids. Limnology and Oceanography 29, 657-663.

Hedges, J. I., and Keil, R. G., 1995. Sedimentary organic matter preservation: an assessment and speculative synthesis. Marine Chemistry 49, 81-115. 
Hedges, J. I., HU, F. S., Devol, A. H., Hartnett, H. E., Tsamakis, E., and Keil, R. G., 1999.

Sedimentary organic matter preservation: a test for selective degradation under oxic conditions. American Journal of Science 299, 529-555.

Henrichs, S. M. and Reeburgh, W. S., 1987. Anaerobic mineralization of marine sediment organic matter: Rates and the role of anaerobic processes in the oceanic carbon economy. Geomicrobiology Journal 5, 191-237.

Honjo, S., Manganini, S. J., Krishfield, R. A., and Francois, R., 2008. Particulate organic carbon fluxes to the ocean interior and factors controlling the biological pump: A synthesis of global sediment trap programs since 1983. Progress in Oceanography 76, 217-285.

Hopkinson, C.J. and Smith E.M., 2005. Estuarine respiration: an overview of benthic, pelagic, and whole system respiration, In: Del Giorgio, P.A. and Williams, P.J. L. [Eds.], Respiration in Aquatic Ecosystems, Oxford University Press, Oxford, pp. 122-146.

Ingalls, A. E., Lee, C., Wakeham, S. G., and Hedges, J. I., 2003. The role of biominerals in the sinking flux and preservation of amino acids in the Southern Ocean along 1701W. Deep-Sea Research II 50, 713-738.

Jennerjahn, T. C. and Ittekkot V., 1997. Organic matter in sediments in the mangrove areas and adjacent continental margins of Brazil: I. Amino acids and hexosamines. Oceanologica Acta 20, $359-369$.

Jørgensen, N. O. G. and Middelboe, M., 2006. Occurrence and bacterial cycling of D amino acid isomers in an estuarine environment. Biogeochemistry 81, 77-94.

Kaiser, K., and Benner, R., 2005. Hydrolysis-induced racemization of amino acids. Limnology and Oceanography Methods 3, 318-325. 
Keil, R. G., Tsamakis, E. C., and Hedges, J. I., 2000. Early diagenesis of particulate amino acids in marine systems, In: Goodfriend, G. A., Collins, M. J., Fogel, M. L., Macko, S. A., Wehmiller, J. F. (Eds.), Perspectives in amino acid and protein chemistry. Oxford Univ. Press. pp. 69-82.

Kristensen, E. and Holmer, M., 2001. Decomposition of plant materials in marine sediment exposed to different electron acceptors (O2, NO3-, and SO4-2), with emphasis on substrate origin, degradation kinetics, and the role of bioturbation. Geochimica et Cosmochimica Acta 65, 419433.

Lee, C., Wakeham, S.G., and Hedges, J. I., 2000. Composition and flux of particulate amino acids and chloropigments in equatorial Pacific seawater and sediments. Deep-Sea Research I 47, 15351568.

Lehmann, M. F., Bernasconi, S. M., Barbieri, A., and McKenzie, J. A., 2002. Preservation of organic matter and alteration of its carbon and nitrogen isotope composition during simulated and in situ early sedimentary diagenesis. Geochimica et Cosmochimica Acta 66, 3573-3584.

Lehmann, M. F., Barnett, B., Gélinas, Y., Gilbert, D., Maranger, R., Mucci, A., Sundby, B. and Thibodeau, B., 2009. Aerobic respiration and hypoxia in the lower St. Lawrence Estuary: Stable isotope ratios of dissolved oxygen constrain oxygen sink partitioning. Limnology and Oceanography 54, 2157-2169.

Lindorth, P. and Mopper, K., 1979. High performance liquid chromatographic determination of subpicomole amounts of amino acids by precolumn flourescence derivatization withophthaldialdehyde. Analytical Chemistry 51, 1667-1674.

Lomstein, B. A., Jørgensen, B. B., Schubert, C. J., and Niggemann, J., 2006. Amino acid biogeo- and stereochemistry in coastal Chilean sediments. Geochimica et Cosmochimica Acta 70, 2970-2989. 
Lomstein, B. A., Niggemann, J., Jørgensen, B. B., and Langerhuus, A. T., 2009. Accumulation of prokaryotic remains during organic matter diagenesis in surface sediments off Peru. Limnology and Oceanography 54, 1139-1151.

Louchouarn, P., Lucotte, M., Camel, R., Gagne, J. P., and Richard, L. F., 1997. Sources and early diagenesis of lignin and bulk organic matter in sediments of the Lower St. Lawrence Estuary and the Saguenay Fjord. Marine Chemistry 58, 3-26.

McCarthy, M. D., Hedges, J. I., and Benner, R., 1998. Major bacterial contribution to marine dissolved organic nitrogen. Science 281, 231-234.

Meckler, A. N., Schubert, C. J., Cowie, G. L., and Dittrich, M., 2004. New organic matter degradation proxies: Valid in lake systems? Limnology and Oceanography 49, 2023-2033.

Mopper, K., and K. G. Furton, 1999. Extraction and analysis of polysaccharides, chiral amino acids, and SFE extractable lipids from marine POM. Geophysical Monograph Series Vol. 63, 151-160. Muzuka, A. N. N. and Hillaire-Marcel C., 1999. Burial rates of organic matter along the eastern Canadian margin and stable isotope constraints on its origin and diagenetic evolution. Marine Geology 160, 251-270.

Niggemann, J., Ferdelman, T. G., Lomstein, B. A., Kallmeyer, J., and Schubert, C. J., 2007. How depositional conditions control input, composition, and degradation of organic matter in sediments from the Chilean coastal upwelling region. Geochimica et Cosmochimica Acta 71, $1513-1527$.

Nunn, B. and R. Keil, G., 2005. Size distribution and amino acid chemistry of base-extractable proteins from Washington coast sediments. Biogeochemistry 75, 177-200.

Pantoja, S., Rossel, P., Castro, R., Cuevas, L. A., Daneri, G. and Córdova, C., 2009. Microbial degradation rates of small peptides and amino acids in the oxygen minimum zone of Chilean coastal waters. Deep-Sea Research II 56, 1055-1062. 
Pedersen, A. G. U., Thomsen, T. R., Lomstein, B. A., and Jørgensen, N. O. G., 2001. Bacterial influence on amino acid enantiomerization in a coastal marine sediment. Limnology and Oceanography 46, 1358-1369.

Rondeau, B., Cossa, D., Gagnon, P., and Bilodeau , L., 2000. Budget and sources of suspended sediment transported in the St. Lawrence River, Canada. Hydrological Processes 14, 21-36.

Roy, S., Blouin, F., Jacques, A., and Therriault, J. C., 2008. Absorption properties of phytoplankton in the Lower Estuary and Gulf of St. Lawrence (Canada). Canadian Journal of Fisheries and Aquatic Sciences 65, 1721-1737.

Schubert, C. J., Niggemann, J., Klockgether, G., and Ferdelman, T. G., 2005. Chlorin Index: A new parameter for organic matter freshness in sediments Geochemistry Geophysics Geosystems 6: Q03005, doi: 10.1029/2004GC000837.

Shankle, A. M., Goericke, R., Franks, P. J. S., and Levin, L. A., 2002. Chlorin distribution and degradation in sediments within and below the Arabian Sea oxygen minimum zone. Deep-Sea Research I 49, 953-969.

Silverberg, N., Bakker, J., Hedenborn, H., and Sundby, B., 1987. Oxygen profiles and organic carbon fluxes in Laurentian Trough sediments. Netherlands Journal of Sea Research 21, 95-105.

Silverberg, N., Sundby, B., Mucci, A., Zhong, S., Arakaki, T., Hall, P., Landen, A., and Tengberg, A., 2000. Remineralization of organic carbon in eastern Canadian continental margin sediments. Deep-Sea Research II 47, 699-731.

Smith, J. N. and Schafer, C. T., 1999. Sedimentation, bioturbation, and Hg uptake in the sediments of the estuary and Gulf of St. Lawrence. Limnology and Oceanography 44, 207-219.

Sun, M. Y., Lee, C., and Aller, R. C., 1993. Laboratory studies of oxic and anoxic degradation of chlorophyll-a in long island sound sediments. Geochimica et Cosmochimica Acta 57, 147-157. 
Thibodeau, B., de Vernal, A. and Mucci, A., 2006. Recent eutrophication and consequent hypoxia in the bottom waters of the Lower St. Lawrence Estuary: Micropaleontological and geochemical evidence. Marine Geology 231, 37-50.

Thibodeau, B., Lehmann, M. F., Kowarzyk, J., Mucci, A., Gélinas, Y., Gilbert, D., Maranger, R., and Alkhatib, M., 2010. Benthic nutrient fluxes along the Laurentian Channel: Environmental controls and impact on the N-budget of the St. Lawrence marine system. Estuarine, Coastal and Shelf Science 90, 195-205.

Tremblay, L. and Benner, R., 2006. Microbial contributions to N-immobilization and organic matter preservation in decaying plant detritus. Geochimica et Cosmochimica Acta 70, 133-146.

Veuger, B., Middelburg, J. J., Boschker, H. T. S., and Houtekamer, M., 2005. Analysis of N incorporation into D-alanine: A new method for tracing nitrogen uptake by bacteria. Limnology and Oceanography Methods 3, 230-240.

Zimmerman, A. R., and Canuel, E. A., 2001. Bulk organic matter and lipid biomarker composition of Chesapeake Bay surficial sediments as indicators of environmental processes. Estuar. Estuarine, Coastal and Shelf Science 53, 319-341. 


\section{Figure captions}

Figure 1: Map showing the sampling locations in the St. Lawrence Estuary (Upper and Lower) and the Gulf of St. Lawrence. Bathymetric contours outline the Laurentian Channel along the 300 and $400 \mathrm{~m}$ isobaths. The size of shadowed circles around study sites denotes bottom water DO concentrations. For absolute values of bottom water DO see Table 1.

Figure 2: (a) $\% \mathrm{C}_{\text {org }}$ and $\% \mathrm{~N}$, (b) $\mathrm{C} / \mathrm{N}$ ratios, THAA $\left(\mu \mathrm{mol} \mathrm{g}{ }^{-1}\right)$, and chlorin concentrations $\left(\mu \mathrm{g} \mathrm{g}^{-1}\right)$, (c) $\delta^{13} \mathrm{C}_{\text {org }}$ and $\delta^{15} \mathrm{~N}(\%)$ and (d) contribution of THAA to $\mathrm{C}_{\text {org }}\left(\%\right.$ THAA-C $\mathrm{C}_{\text {org }}$ ) and N (\%THAA-N) in surface sediments in the St. Lawrence Estuary and the Gulf of St. Lawrence.

Figure 3: Down-core sediment records in the Lower St. Lawrence Estuary and the Gulf of St. Lawrence: (a) $\% \mathrm{C}_{\text {org }}$, (b) $\% \mathrm{~N}$, (c) $\mathrm{C} / \mathrm{N}$ ratios, (d) $\delta^{13} \mathrm{C}_{\text {org }}\left(\%\right.$ ), (e) $\delta^{15} \mathrm{~N}(\%$ ) , (f) chlorin index (CI) (\%o), and (g) chlorin concentrations $\left(\mu \mathrm{g} \mathrm{g}^{-1}\right)$.

Figure 4: OM reactivity indices in surface sediments in the St. Lawrence Estuary and the Gulf of St. Lawrence.

Figure 5: Down-core profiles of (a) THAA $\left(\mu \mathrm{mol} \mathrm{g}{ }^{-1}\right)$, (b) \% THAA-C ${ }_{\text {org }}$, (c) \%THAA-N, (d) D/L Ala, and (e) DI scores at Sta. 23 in the Lower Estuary and Sta. 18 in the Gulf.

Figure 6: Amino acid distribution (mole\% of THAA) in sediments down-core at Sta. 23 in the Lower Estuary and Sta. 18 in the Gulf. 
Figure 7: Correlation between the chlorin index (CI) and (a) the degradation index (DI) and (b) the reactivity index $(\mathrm{RI})$ in surface sediments along the St. Lawrence Estuary and the Gulf of St. Lawrence. The labels next to data points refer to the station names. The circle denotes the shallow locations in the Upper Estuary.

Figure 8: Correlation between CI in surface sediments and (a) water column depth, (b) $\mathrm{C}_{\text {org }}$ vertical flux, and (c) dissolved oxygen in bottom water (DO; $\left.\mu \mathrm{mol} \mathrm{L}{ }^{-1}\right)$. The labels next to data points refer to the station names. The circle denotes the shallow locations in the Upper Estuary. 
Table 1: Sampling site characteristics along the St. Lawrence estuary and the Gulf of St.

Lawrence. Chlorin loss (in \%) defined as: $\left.\left([\mathrm{Chlr}]_{1 \mathrm{~cm}}-[\mathrm{Chlr}]_{5 \mathrm{~cm}}\right) /[\mathrm{Chlr}]_{1 \mathrm{~cm}} \times 100\right) .(\mathrm{ND}=$ not determined).

\begin{tabular}{|c|c|c|c|c|c|c|c|c|c|c|}
\hline Station & $\begin{array}{l}\text { Distance from } \\
\text { DE }(\mathrm{km})\end{array}$ & $\begin{array}{l}\text { Depth } \\
\text { (m) }\end{array}$ & $\begin{array}{c}\text { Bottom water } \\
{\left[\mathrm{O}_{2}\right]^{\text {(a) }}} \\
\left(\mu \mathrm{mol} \mathrm{L}^{-1}\right)\end{array}$ & $\begin{array}{c}\text { OET } \\
\text { (years) }\end{array}$ & $\begin{array}{l}\text { OPD } \\
(\mathrm{cm})\end{array}$ & $\begin{array}{c}\text { Sediment acc. } \\
\text { Rate }^{(\mathrm{a})} \\
\left(\mathrm{g} \mathrm{cm}^{-2} \mathrm{yr}^{-1}\right)\end{array}$ & $\begin{array}{c}\mathrm{C}_{\text {org flux }} \text { flux } \\
\left(\mu \mathrm{mol} \mathrm{cm} \mathrm{yr}^{-1}\right)\end{array}$ & $\begin{array}{l}\mathrm{C}_{\text {org burial rate }} \text { bul } \\
\left(\mu \mathrm{mol} \mathrm{cm} \mathrm{yr}^{-1}\right)\end{array}$ & $\begin{array}{l}\text { Chlorin conc. } \\
\left(\mu \mathrm{g} / 100 \mathrm{mg} \mathrm{C} \mathrm{C}_{\mathrm{org}}\right)\end{array}$ & $\begin{array}{c}\text { Chlorin loss } \\
(\%)\end{array}$ \\
\hline$\overline{\mathrm{DE}}$ & 0 & 23 & 290 & N.D. & N.D. & N.D. & N.D. & N.D. & 62.4 & N.D. \\
\hline G & 40 & 93 & 290 & N.D. & N.D. & N.D. & N.D. & N.D. & 60.2 & N.D. \\
\hline $\mathrm{H}$ & 70 & 64 & 291 & N.D. & N.D. & N.D. & N.D. & N.D. & 76.8 & N.D. \\
\hline 25 & 162 & 290 & 65 & 1.17 & 0.64 & 0.55 & N.D. & N.D. & 81.2 & 49 \\
\hline 23 & 226 & 350 & 63 & 1.72 & 0.92 & 0.45 & 471 to $932^{\text {(c) }}$ & $\sim 108$ to $364^{(\mathrm{c})}$ & 44.5 & 34 \\
\hline 22 & 304 & 321 & 70 & N.D. & N.D. & 0.45 & $573^{\text {(d) }}$ & $\sim 158^{\text {(d) }}$ & 77.5 & 46 \\
\hline 21 & 350 & 330 & 75 & 6.57 & 1.46 & 0.22 & N.D. & N.D & 58.5 & 42 \\
\hline 20 & 442 & 330 & 97 & N.D. & N.D. & 0.14 & $\sim 22^{\text {(e) }}$ & $\sim 13^{\text {(e) }}$ & 46.1 & 39 \\
\hline 19 & 526 & 370 & 108 & 7.68 & 1.82 & 0.24 & 66 to $160^{(\mathrm{f})}$ & $\sim 46^{(\mathrm{f})}$ & 53.5 & 41 \\
\hline 18 & 586 & 370 & 123 & 13.57 & 1.56 & 0.12 & $\sim 19^{(\mathrm{e})}$ & $\sim 10^{(\mathrm{e})}$ & 42.7 & 25 \\
\hline Anticosti & 765 & 283 & 106 & N.D. & 1.53 & N.D. & N.D. & $\sim 13^{(\mathrm{e})}$ & 26.5 & 29 \\
\hline 16 & 820 & 420 & 197 & N.D. & N.D. & 0.04 & $\sim 22^{\text {(e) }}$ & $\sim 11^{(\mathrm{e})}$ & 21.3 & 17 \\
\hline
\end{tabular}

Data from: ${ }^{(a)}$ Thibodeau et al. (2010); ${ }^{(b)}$ Smith and Schafer (1999); ${ }^{(c)}$ Silverberg et al. (1987);

${ }^{(\mathrm{d})}$ Colombo et al. (1996); ${ }^{(\mathrm{e})}$ Muzuka and Hillaire-Marcel (1999); ${ }^{(\mathrm{f})}$ Silverberg et al. (2000) 
Table 2: Amino acids (mole- $\%$ of THAA) in surface sediments along the St Lawrence Estuary

(Sta. DE - 21) and the Gulf of St. Lawrence (Sta. 20 to 16).

\begin{tabular}{|c|c|c|c|c|c|c|c|c|c|c|c|c|c|c|c|c|c|c|}
\hline Station & Ala & $\mathrm{D} / \mathrm{L}$ Ala & Arg & Asp & BALA & GABA & Glu & Gly & His & ILeu & Leu & Lys & Met & Phe & Ser & Thr & Tyr & $\mathrm{Val}$ \\
\hline $\mathrm{DE}$ & 8.1 & 0.17 & 3.8 & 13.3 & 0.6 & 1.0 & 10.6 & 15.7 & 2.0 & 3.6 & 5.4 & 7.4 & 0.4 & 2.7 & 8.0 & 7.8 & 1.6 & 7.6 \\
\hline G & 8.2 & 0.16 & 3.9 & 13.8 & 0.9 & 1.3 & 10.2 & 15.8 & 2.1 & 3.9 & 5.7 & 6.9 & 0.4 & 3.2 & 7.9 & 6.9 & 1.5 & 7.5 \\
\hline $\mathrm{H}$ & 8.1 & 0.21 & 3.6 & 13.5 & 1.2 & 1.6 & 10.5 & 15.2 & 1.9 & 3.5 & 4.5 & 8.1 & 0.6 & 3.0 & 8.2 & 7.4 & 1.6 & 7.4 \\
\hline 25 & 8.3 & 0.24 & 3.7 & 15.5 & 1.1 & 1.7 & 10.2 & 15.8 & 1.4 & 3.5 & 4.7 & 6.4 & 0.6 & 2.4 & 8.1 & 8.0 & 1.5 & 7.1 \\
\hline 23 & 8.9 & 0.22 & 3.8 & 15.4 & 1.8 & 1.5 & 10.3 & 16.1 & 1.4 & 3.4 & 4.3 & 4.4 & 0.5 & 2.8 & 8.9 & 7.3 & 1.6 & 7.6 \\
\hline 22 & 7.8 & 0.23 & 3.6 & 16.7 & 2.1 & 1.7 & 9.2 & 16.8 & 1.8 & 3.1 & 3.8 & 5.4 & 0.4 & 2.5 & 8.4 & 7.7 & 1.7 & 7.3 \\
\hline 21 & 7.4 & 0.25 & 4.3 & 15.7 & 2.1 & 1.5 & 9.7 & 17.2 & 1.7 & 3.0 & 3.9 & 4.9 & 0.6 & 2.6 & 8.5 & 7.8 & 1.6 & 7.3 \\
\hline 20 & 7.5 & 0.31 & 4.2 & 16.6 & 2.5 & 1.7 & 9.8 & 16.6 & 1.9 & 3.2 & 4.3 & 3.9 & 0.7 & 2.2 & 8.3 & 8.3 & 1.3 & 7.1 \\
\hline 19 & 7.2 & 0.4 & 4.7 & 15.8 & 2.6 & 1.8 & 9.0 & 17.8 & 1.6 & 3.0 & 3.8 & 4.9 & 0.7 & 2.3 & 8.0 & 7.9 & 1.4 & 7.6 \\
\hline 18 & 8.6 & 0.34 & 4.5 & 16.0 & 2.4 & 1.6 & 9.2 & 16.9 & 1.7 & 3.2 & 3.2 & 5.2 & 0.6 & 2.6 & 8.9 & 6.6 & 1.3 & 7.5 \\
\hline Anticosti & 7.5 & 0.28 & 4.0 & 16.2 & 2.4 & 1.5 & 9.0 & 17.1 & 1.4 & 3.3 & 3.8 & 6.9 & 0.5 & 2.5 & 7.7 & 7.6 & 1.5 & 7.0 \\
\hline 16 & 7.4 & 0.42 & 4.7 & 17.1 & 2.9 & 1.7 & 8.7 & 19.5 & 1.5 & 2.7 & 2.9 & 4.4 & 0.4 & 2.3 & 7.5 & 8.1 & 1.3 & 7.0 \\
\hline
\end{tabular}

